\title{
LVII. Descriptive notice of the Morro Velho mine, province of minas Geraës; and on the relations between the structure of the containing rocks and the directions of the shoots of gold in the Brazilian mines
}

William Jory Henwood C.E. F.R.S. F.G.S.

To cite this article: William Jory Henwood C.E. F.R.S. F.G.S. (1844) LVII. Descriptive notice of the Morro Velho mine, province of minas Geraës; and on the relations between the structure of the containing rocks and the directions of the shoots of gold in the Brazilian mines, Philosophical Magazine Series 3, 25:167, 341-344, DOI: 10.1080/14786444408645008

To link to this article: http://dx.doi.org/10.1080/14786444408645008

曲 Published online: 30 Apr 2009.

Submit your article to this journal $\widetilde{ }$

Џ Article views: 2 
bonic acid; and to this circumstance we must ascribe the effect of the blue ray as shown by Mr. Hunt's experiments.

I should feel obliged if you would insert this in the Philosophical Magazine, as it would perhaps attract the attention of those who are engaged in experiments on this subject.

Ormskirk, August 21, 1844.

I am, Sir, your obedient Servant,

Roberi Harkness.

LVII. Descriptive Notice of the Morro Velho Mine, Province of Minas Geraës; and on the Relations between the Structure of the Containing Rocks and the Directions of the Shoots of Gold in the Brazilian Mines. By Wildiam Jony Henwoon, C.E., F.R.S., F.G.S., Chief Commissioner of the Gongo Soco Gold Mines*.

rTHE gold mine of Morro Velho is about 48 miles northwest of the city of Ouro Preto and 10 miles south of the town of Sabará: it has been worked by English companies for nearly sixteen years, but unsuccessfully until within three years past.

It is situated on the flank of a mountain of considerable elevation; to the contour of which the metalliferous mass has an approximate parallelism, a circumstance of frequent occurrence in the gold formations of Brazil.

$a$. The rock mostly consists of a dark lead-coloured clayslate, and occasionally contains traces of chlorite, whilst there are some layers of a dark brown colour, and others which are quartzose and have a crystalline structure. The general bearing of the lamination is from N.E. to S.W., and the dip is usually towards the S.E. from $40^{\circ}$ to $70^{\circ}$. One series of joints bears about E. and W., and another N. and S. (magnetic).

$b$. The direction, dip, and dimensions of the mass from which the gold is extracted are very irregular, and although it has some characters in common with metalliferous veins (lodes), it has others which more nearly resemble the formations of tin ore at the Saint Ives Consolst, Rosewall Hill †, and Balnoon $\oint$. 'The accompanying ground plan is copied from that used at the mine, and exhibits the peculiarities of this formation more clearly than any description could do.

The most westerly part of the mine is called the Champion Ground, and consists of an assemblage of small veins; these unite with the little Quebra Panella, which dips N. $70^{\circ}-80^{\circ}$, and is, on an average, about eighteen feet wide, although in this respect it varies very much in different parts. Eastward

* Communicated by the Author.

$\uparrow$ Cornwall Geol. Trans., vol. v. p. 21.

₹ Ibid. p. 237 .

\$ Ibid. p. 24, 
this joins the great Quebra Panella, which inclines towards the S. $60^{\circ}-75^{\circ}$, and, although of very irregular dimensions, its

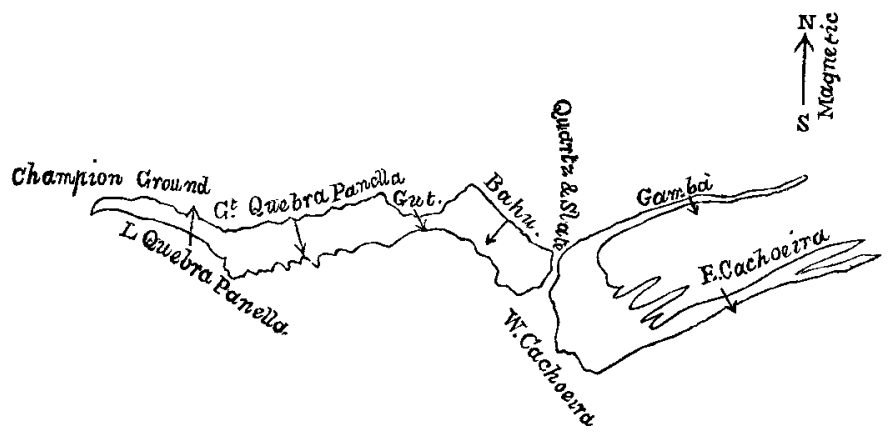

greatest breadth is not less than forty-eight feet. The Gut forms the prolongation eastward, and dips S.E., parallel to the cleavage of the contiguous slate rock: the widest parts of this are not more than eight feet in breadth, and the greater portion is much narrower. Connected with the last-named part, on the E., is the Bahu, which underlies S., and is, on an average, about twenty-four feet wide. A bed of quartzose slate, slightly charged with iron pyrites, separates the Bahu from the Western Cachoeira, which is at present unwrought and inaccessible. Two principal veins and several smaller ones branch off from the Western Cachoeira; the most northerly is the Gambà, which dips S., and is from two to eight feet in breadth; the other, called the Eastern Cachoeira or Luiza, has about the same width and inclination, and still further eastward also divides into other and smaller veins.

c. The mineral composition of the Champion Ground is quartzose slate, thinly spotted with pyrites. That of the other productive portions is, for the most part, very arsenical iron pyrites, more or less mixed with quartz and a little slaty matter, and frequently spotted with copper pyrites. Occasionally, too, isolated masses of black quartz and of copper pyrites are found, as well as cavities (oughs) lined with crystals of quartz and of arragonite. It is with these ingredients that the gold is mixed, and here, as in the greater number of Brazilian mines, the richer parts are usually near the upper side (hanging wall) of the vein ; the metal is however seldom, or never, distinguishable in the stone.

The shallower part of the Eastern Cachoeira consists of earthy-brown iron ore (gossan), interspersed with stones of iron and copper pyrites.

$d$. The connexion between the metalliferous mass and the contiguous rock is by a gradual transition, the pyritous matter 
being gradually replaced by quartzose and slaty substances towards the sides of the vein, much as in many Cornish mines*. Joints also sometimes intervene and give a deceptive appearance of distinct demarcations (smooth roalls) between them; in such cases, however, the mineral composition is much alike on both sides of the joints + . On the upper side (hanging wall) of the great Quebra Panella the pyrites and the adjoining slate mutually penetrate each other, giving rise to a serrated appearance.

$e$. The metallic minerals when brought to the surface are spalled and stamped, as tin ores and the poorer copper ores are in Cornwall; and the gold is afterwards separated from the other ingredients by amalgamation.

$f$. During the month of December 1843, the pyrites extracted from the mine was 2168 tons, and it yielded 110 troy lbs. of gold, or about 292 grains of gold from each ton of oref.

g. All the machinery is worked by water, and about 70 Europeans and 700 negroes are employed.

$h$. The quantity of water in the mine is inconsiderable; at about forty-two fathoms deep in the Bahu it issues from the vein at a temperature of $68^{\circ}$; and somewhat shallower, in the Eastern Cachoeira, at $69^{\circ}$.

The richer portions of the vein at Morro Velho, as in all other mines, are connected by vein-stones of a less metallic composition. There are however four well-marked enlargements of it, which respectively preserve the same relative positions, the same configuration, and indeed almost exactly the same dimensions, at every other portion of their descent yet seen, as they expose in their outcrop at the surface. They have a regular inclination of about $45^{\circ}$ towards the $\mathrm{E}$., on a line which bears $2^{\circ} \mathrm{N}$. of W. (magnetic); and this regularity equally prevails, whether the dip of the vein may be parallel or oblique to the cleavage of the containing rock, whether it may be uniform or variable.

A circumstance of value to the miner, as well as of interest to the geologist, is however common to most, if not to all, of the Brazilian mines; namely, that whether the veins may be parallel, transverse, or oblique to the schistose structure of the rock, their sides (walls) are grooved or fluted with large striæ, which are coincident with the dips of the shoots of gold, both in the angles and directions of their inclinations.

These facts are most conspicuous at Morro Velho, where the gold is dispersed through pyrites, and the rock is clayslate; at Gongo Soco, where enormous masses of gold occur

- Cornwall Geol. Trans., vol. v. p. 185.

$\ddagger$ Mining Journal, 1844, March 16th. 


\section{Dr. Joseph Reade on Electro-Rotatory Points,}

in manganesic oxide of iron (jacotinga), and the rock is schistose specular iron ore; and at Catta Preta, where the veinstone is quartz, and the country quartzose sandstone. At Gongo Soco the shoots dip eastward from the granitoid rocks of the Serra de Tejuco, whilst at Catta Preta they incline westward from similar rocks near Inficionada.

There is not only a remarkable similarity between these facts and the disposition of the shoots of ore in Cornwall and Devon*, but the striæ present a second class of phænomena, which are either less conspicuous $\dagger$ or altogether wanting there.

There are some remarkable analogies between the arrangement of gold in Brazil and that of tin ore in Cornwall, but I reserve their discussion until another opportunity.

The auriferous rocks of Brazil afford but few data for assigning their geological epoch; there is, however, much probability that they may eventually be found the equivalents of the metalliferous formations of the West of England.

Gongo Soco Gold Mines, June 29, 1844.

W. J. Henwood.

LVIII. On Electro-Rotatory Points, and the Pyro-Electricity of Glass. By Joseph Reade, Esq., M.D.

TN the year $1750 \mathrm{Dr}$. Franklin made a number of experiments to ascertain the attractions and discharges of the electric force from points, but as these points were fixed, such as a needle held in the hand before a conductor, or a shoemaker's punch under a pair of excited scales to represent the clouds, Dr. Franklin says " he could not account for the attractions." If the scales were electro-positive, the punch must have been electro-negative. Rotatory points were first used in 1660 by Dr. Gilbert (described in his work De Magnete). This instrument at present, with some little alterations, is known as Haüy's electroscope, and consists of a slender wire revolving on a pivot, and armed at both ends with gilt pith-balls. In the year 1785, a celebrated French philosopher, Coulomb, invented the balance of torsion, and turned his attention to electric points, but as they were fixed, like those of Franklin, the same objections remain. Indeed the only revolving points were the electric fly and the electric orrery, and in these the revolutions were erroneonsly attributed to recoil between the air and the electric force when discharged,-a physical impossibility. An imponderable acting on a ponderable substance is unknown in the science of statics; as well might light recoil.

* Cornwall Geol. Trans, vol. v. p. 193. Edin. New Phil. Journal, vol. xxii. p. 157.

+ Cornwall Geol. Trans., vol. v. p. 182.

$\ddagger$ Communicated by the Author, through Mr. E. W. Brayley. 